\title{
LETTER
}

\section{Zaïrite in quartz veins from Ishidera area, Wazuka, Kyoto Prefecture, Japan}

\author{
Yuma Morimitsu*, Yohei Shirose $^{* *}$, Satomi EnJu**, Kenji TsurutA ${ }^{\dagger}$ and Norimasa ShimobaYAShi* \\ *Department of Geology and Mineralogy, Graduate School of Science, Kyoto University, Kyoto 606-8502, Japan \\ ** Department of Earth's Evolution and Environment, Graduate School of Science and Engineering, \\ Ehime University, Matsuyama 790-0826, Japan \\ ${ }^{* * *}$ The Kyoto University Museum, Kyoto University, Kyoto 606-8501, Japan \\ ${ }^{\dagger}$ Fine Art Division, Faculty of Fine Arts, Kyoto City University of Arts, Kyoto 610-1197, Japan
}

\begin{abstract}
Zairite was found from the quartz vein penetrating into the metamorphosed mudstone of the Wazuka Unit in Ishidera area, Wazuka-cho, Kyoto Prefecture, Japan, which is the first occurrence in Japan. Zaïrite occurs as bright-yellow granular crystals $(20-30 \mu \mathrm{m})$ in a cavity formed by the leaching of fluorapatite with native bismuth inclusion. The chemical composition of zaïrite from Ishidera was closer to the ideal chemical composition, comparing with the zaïrite from type locality including Al. The empirical formula from electron probe microanalyzer (EPMA) analysis on the basis of $\mathrm{O}=8, \mathrm{OH}^{-}=6$ was $\left(\mathrm{Bi}_{0.70} \mathrm{Ca}_{0.23}\right)_{\Sigma 0.93} \mathrm{Fe}_{2.91}^{3+}\left(\mathrm{P}_{2.04} \mathrm{~S}_{0.09} \mathrm{O}_{8}\right)(\mathrm{OH})_{6}$. The unit cell parameters obtained from the X-ray diffraction (XRD) pattern were $a=7.311(3) \AA$ and $c=16.407(7) \AA$, larger than the type locality due to difference in chemical composition.
\end{abstract}

Keywords: Zaïrite, Waylandite, Plumbogummite group, Ishidera, Wazuka

\section{INTRODUCTION}

The Wazuka district, located in southern Kyoto Prefecture, is situated at the northern margin of the Cretaceous Ryoke low-pressure/temperature (low- $P / T$ ) metamorphic belt stretching along the Median Tectonic Line, Southwest Japan. In this district, the Late Jurassic accretionary complex of the Tamba belt (Wazuka Unit) is widely distributed as the protolith of the low- to high-grade metamorphic rocks (Wang et al., 1986; Takeuchi and Wang, 1999; Ozaki et al., 2000). The Wazuka Unit is mainly composed of mudstone and bedded chert. Ozaki et al. (2000) studied the paragenesis of pelitic and psammitic metamorphic rocks in the Wazuka district and divided into four mineral zones; chlorite zone, chlorite-biotite zone, biotite zone, and sillimanite zone, in order of increasing metamorphic grade. In the northern area of the district, Late Cretaceous granitic rocks (the Younger Ryoke granitic rocks) were intruded discordantly into the regional metamorphic rocks. Contact aureole is recognized as a cordierite zone

doi:10.2465/jmps.201130d

Y. Morimitsu, morimitsu.yuma.t59@kyoto-u.jp Corresponding author

N. Shimobayashi, shimobayashi.norimasa.6r@kyoto-u.ac.jp between biotite and sillimanite zones (Ozaki et al., 2000). At the present sampling locality in the Ishidera area, corresponding to the cordierite zone, a number of quartz veins penetrates into the metamorphosed mudstone of the Wazuka Unit. These quartz veins are grayish and mainly composed of quartz and minor amount of muscovite, feldspar, fluorapatite, scheelite, beryl, tourmaline, pyrite, and native bismuth. Some secondary minerals are reported; phosphates (cacoxenite, phosphosiderite, strengite, and waylandite), tungsten minerals (ferritungstite, russelite, anthoinite, and mpororoite), bertrandite, and goethite (Tsuruta et al., 2008; Shimobayashi et al., 2012; Shirose et al., 2018). We have newly found a secondary phosphate mineral 'zaïrite' formed by alteration of fluorapatite in the quartz veins in the Ishidera area, which is the first occurrence in Japan.

Zaïrite $\left[\mathrm{BiFe}_{3}^{3+}\left(\mathrm{PO}_{4}\right)_{2}(\mathrm{OH})_{6}\right]$ was first found in the weathering zone of quartz veins mineralized in wolframite at Eta-Etu, North Kivu, Zaïre (now the Democratic Republic of the Congo) by Wambeke (1975). Wambeke considered this greenish-colored mineral as the ferric iron analogue of waylandite, both of which belongs to the crandallite series (space group: $R \overline{3} \mathrm{~m}$ ), plumbogummite group mineral. Wambeke (1975) derived its structural formula 

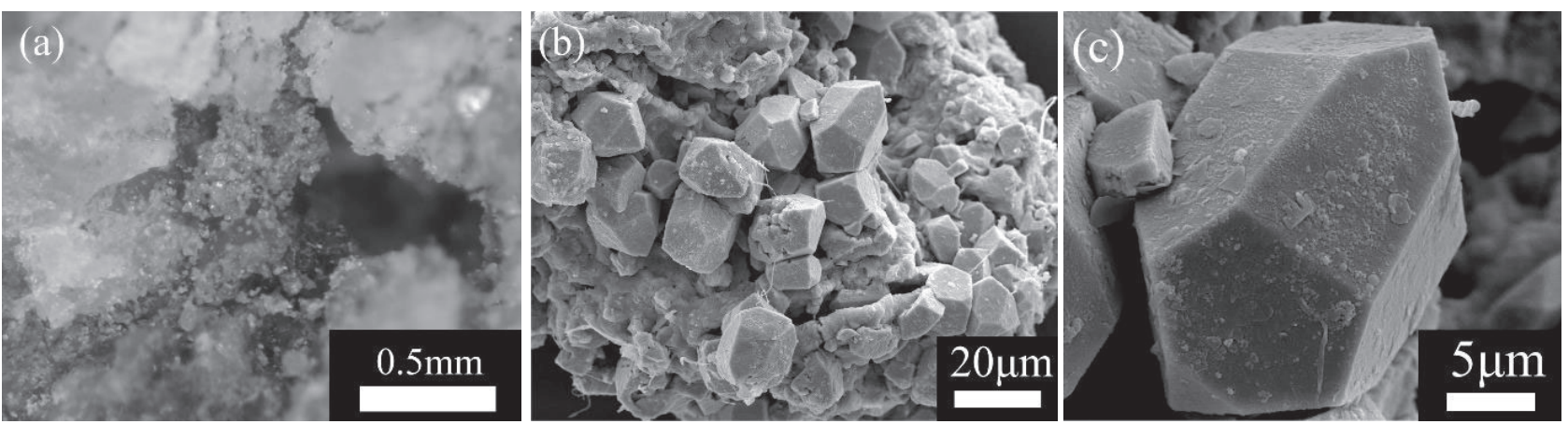

Figure 1. Photographs of zaïrite from the Ishidera area, Wazuka, Japan. (a) Bright-yellow granular crystals in a cavity formed by the leaching of fluorapatite. (b) Secondary electron image of zaïrite showing aggregated crystals. (c) Secondary electron image of zaïrite showing a short hexagonal prismatic crystal. Color version is available online from https://doi.org/10.2465/jmps.201130d.

from the chemical analysis as $\left[\mathrm{Bi}_{0.76}(\mathrm{Ba}, \mathrm{Ca}, \mathrm{Cu}, \mathrm{Zn})_{0.23}\right.$ $\left.\mathrm{H}_{0.23}\right]\left[\mathrm{Fe}_{2.38} \mathrm{Al}_{0.65}\right]\left[\left(\mathrm{PO}_{4}\right)_{1.91}\left(X \mathrm{O}_{4}\right)_{0.09}\right](\mathrm{OH})_{6}$, where $X=$ $\mathrm{Si}, \mathrm{S}, \mathrm{Te}, \mathrm{H}_{4}$, and its unit cell parameters as $a=7.015(5)$ $\AA$ and $c=16.365(15) \AA$. Geological setting of this type material is granite pegmatite. After its discovery in 1975, the occurrence of zairite has been reported from a few localities in the world. The mineralogical properties, especially unit cell parameters, of zaïrite from Ishidera was quite different from the type locality. For further understanding of the mineralogical properties of zaiirite and plumbogummite group mineral, the present paper reports the occurrence and mineralogical properties of zaïrite from Ishidera area, Wazuka-cho, Kyoto Prefecture, Japan.

\section{SAMPLES AND METHODS}

\section{Sample description}

The samples used in this study are collected from the grayish quartz vein including muscovite and fluorapatite. The grayish quartz at this locality is characterized by including the numerous fine particles $(<10 \mu \mathrm{m})$ of graphite. In addition to sulfide minerals such as pyrite and chalcopyrite, aggregates of native sulfur are often observed in the grayish quartz vein. There are some cavities formed by the leaching of fluorapatite out from the quartz vein. Zairite occurs in this type of cavity, as aggregates of bright-yellow granular crystals $(<20 \mu \mathrm{m})$ with glassy luster (Fig. 1a). Other secondary phosphate minerals such as strengite and beraunite are also coexistent in the cavity.

\section{Analytical methods}

Chemical analyses were performed on a JEOL JXA-8105 electron probe micro-analyzer (EPMA) equipped with a wavelength dispersive X-ray spectrometer. Quantitative analyses were performed at an accelerating voltage of 15 $\mathrm{kV}$, beam current of $3 \mathrm{nA}$, and probe diameter of $3 \mu \mathrm{m}$.
The standard materials were bismuth selenide (for $\mathrm{Bi} M \alpha$ ), corundum (for $\mathrm{Al} K \alpha$ ), hematite (for $\mathrm{Fe} K \alpha$ ), diopside (for $\mathrm{Ca} K \alpha$ ), jadeite (for $\mathrm{Na} K \alpha$ ), apatite (for $\mathrm{P} K \alpha$ ) and sphalerite (for $\mathrm{S} K \alpha$ ). The ZAF method was used for data correction. Morphological observations were carried out using a JEOL JSM-6060 scanning electron microscope (SEM). $\mathrm{X}$-ray diffraction (XRD) data of this mineral was collected by using a randomized Gandolfi-like motion by two axes (oscillation on $\omega$ and rotation on $\varphi$ ) in a Rigaku RINT RAPID II curved imaging plate microdiffractometer at Kyushu University, with utilized monochromatized $\mathrm{CuK \alpha}$ radiation generated at $40 \mathrm{kV}$ and $30 \mathrm{~mA}$.

\section{DESCRIPTION OF MINERALS}

Morphological observation with SEM shows that zaïrite occurs as short hexagonal prismatic crystal up to $20 \mu \mathrm{m}$ in size (Figs. 1b and 1c). As shown in Figure 2, zaïrite occurs in association with other bismuth phosphates less than $10 \mu \mathrm{m}$, in the cracks and cavities formed by the leaching of fluorapatite including native bismuth as an inclusion $(<10 \mu \mathrm{m})$. This indicates the formation of zairite by the

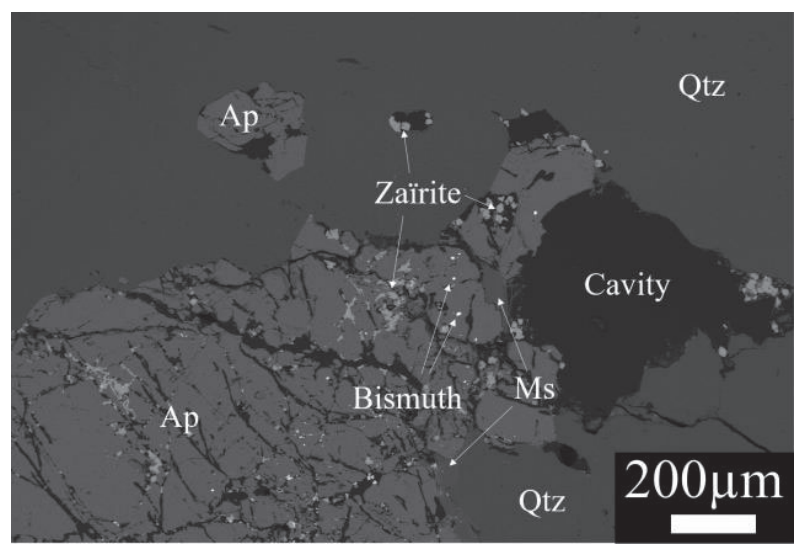

Figure 2. Backscattered electron image of zaïrite and associated minerals. Ap, fluorapatite; Ms, muscovite; Qtz, quartz. 
Table 1. Representative XRD data for zaïrite

\begin{tabular}{|c|c|c|c|c|}
\hline \multirow[b]{2}{*}{$h k l$} & \multicolumn{2}{|c|}{1} & \multicolumn{2}{|c|}{2} \\
\hline & $d_{\text {meas. }}$ & $I$ & $d_{\text {meas. }}$ & $I$ \\
\hline 101 & 5.890 & 100 & 5.710 & 95 \\
\hline 0112 & 5.011 & 3 & 4.870 & 10 \\
\hline 110 & 3.641 & 19 & 3.500 & 40 \\
\hline 021 & 3.098 & 14 & & \\
\hline 113 & 3.031 & 89 & 2.945 & 100 \\
\hline $\begin{array}{lll}20 & 2\end{array}$ & 2.944 & 12 & 2.851 & 15 \\
\hline $\begin{array}{lll}0 & 0 & 6\end{array}$ & 2.739 & 13 & 2.727 & 20 \\
\hline 024 & 2.502 & 12 & 2.440 & 10 \\
\hline 122 & 2.353 & 2 & & \\
\hline 205 & 2.285 & 2 & & \\
\hline 107 & 2.199 & 26 & 2.184 & 10 \\
\hline 116 & & & 2.158 & 15 \\
\hline 033 & 1.963 & 12 & & \\
\hline $\begin{array}{lll}30 & 0\end{array}$ & & & 1.897 & 15 \\
\hline 220 & 1.821 & 13 & 1.754 & 10 \\
\hline 208 & 1.719 & 8 & & \\
\hline 223 & & & 1.670 & 5 \\
\hline 119 & 1.631 & 5 & & \\
\hline $\begin{array}{lll}10 & 10\end{array}$ & 1.589 & 1 & & \\
\hline 226 & 1.516 & 7 & & \\
\hline $\begin{array}{lll}02 & 10\end{array}$ & 1.457 & 14 & & \\
\hline & $a=7.3$ & (3) $\AA$ & $a=7$. & $5(5) \AA$ \\
\hline & $c=16.4$ & 7) $\AA$ & $c=16$ & (15) $\AA$ \\
\hline
\end{tabular}

1. Zaïrite from Ishidera, Wazuka, Japan (Present work).

2. Zaïrite from Eta-Etu, northern Kivu, Congo (Wambeke, 1975; ICDD-PDF 00-029-0226).

alteration of fluorapatite, pyrite, and native bismuth.

The XRD pattern of zaïrite from Ishidera does not well match the XRD pattern of zaïrite from type locality descripted by Wambeke (1975) or PDF card \#00-0290226, due to the difference in chemical composition, which will be explained in the discussion section. The obtained peaks were indexed using a simulated crystal structure of zairite based on the atomic parameter of waylandite, an $\mathrm{Al}$ analogue of zaïrite (Mills et al., 2010). The unit cell parameters of zaïrite from Ishidera were obtained as trigonal cell: $a=7.311(3) \AA, c=16.407(7) \AA$, and $V=$ 759.5(6) $\AA^{3}$ (Table 1).

The chemical composition of zaïrite from Ishidera was closer to the ideal chemical composition, comparing with the zaiirite from type locality including Al. The empirical formula from EPMA analysis on the basis of $\mathrm{O}=8$, $\mathrm{OH}^{-}=6$ was $\left(\mathrm{Bi}_{0.70} \mathrm{Ca}_{0.23}\right)_{\Sigma 0.93} \mathrm{Fe}_{2.91}^{3+}\left(\mathrm{P}_{2.04} \mathrm{~S}_{0.09} \mathrm{O}_{8}\right)(\mathrm{OH})_{6}$ (Table 2). Al was not measured in quantitative analysis because it was not detected in qualitative analysis. The total was $92 \mathrm{wt} \%$ including calculated $\mathrm{H}_{2} \mathrm{O}$, and this lower value may be due to minor beam damage, as in the case of waylandite reported by Mills et al. (2010), which belongs to the same group with zaiirite. Some grains of zaiirite show slight chemical zoning along the shape of the crystal.
Table 2. Chemical compositions of zaïrite

\begin{tabular}{|c|c|c|c|}
\hline & \multicolumn{2}{|c|}{1} & \multirow[t]{2}{*}{2} \\
\hline & $\begin{array}{l}\text { Average of } \\
7 \text { points }\end{array}$ & $\begin{array}{r}\text { Standard } \\
\text { deviation }\end{array}$ & \\
\hline \multicolumn{4}{|l|}{$\overline{W t} \%$} \\
\hline $\mathrm{Bi}_{2} \mathrm{O}_{3}$ & 24.44 & 0.98 & 28.71 \\
\hline $\mathrm{BaO}$ & - & - & 1.98 \\
\hline $\mathrm{CaO}$ & 1.90 & 0.46 & 0.72 \\
\hline $\mathrm{CuO}$ & - & - & 0.82 \\
\hline $\mathrm{ZnO}$ & - & - & 0.82 \\
\hline $\mathrm{Fe}_{2} \mathrm{O}_{3}$ & 34.77 & 1.25 & 30.75 \\
\hline $\mathrm{Al}_{2} \mathrm{O}_{3}$ & *n.d. & $*$ n.d. & 5.35 \\
\hline $\mathrm{P}_{2} \mathrm{O}_{5}$ & 21.65 & 0.78 & 21.93 \\
\hline $\mathrm{SiO}_{2}$ & - & - & 0.33 \\
\hline $\mathrm{SO}_{3}$ & 1.04 & 0.28 & 0.29 \\
\hline $\mathrm{TeO}_{3}$ & - & - & 0.20 \\
\hline $\mathrm{H}_{2} \mathrm{O}$ & $* * 8.09$ & $* * 0.28$ & 9.05 \\
\hline Total & 91.89 & 2.50 & 100.18 \\
\hline \multicolumn{4}{|c|}{ Mole ratios (basis: $\mathrm{O}=8, \mathrm{OH}^{-}=6$ ) } \\
\hline $\mathrm{Bi}$ & 0.70 & 0.04 & 0.760 \\
\hline $\mathrm{Ba}$ & - & - & 0.080 \\
\hline $\mathrm{Ca}$ & 0.23 & 0.05 & 0.080 \\
\hline $\mathrm{Cu}$ & - & - & 0.064 \\
\hline $\mathrm{Zn}$ & - & - & 0.004 \\
\hline $\mathrm{Fe}^{3+}$ & 2.91 & 0.03 & 2.380 \\
\hline $\mathrm{Al}$ & *n.d. & ${ }^{*}$ n.d. & 0.650 \\
\hline $\mathrm{P}$ & 2.04 & 0.02 & 1.910 \\
\hline $\mathrm{Si}$ & - & - & 0.034 \\
\hline S & 0.09 & 0.08 & 0.023 \\
\hline $\mathrm{Te}$ & - & - & 0.007 \\
\hline $\mathrm{OH}^{-}$ & 6 & $=$ & 6 \\
\hline
\end{tabular}

1. Zaïrite from Ishidera, Wazuka, Japan (Present work).

2. Zaïrite from Eta-Etu, northern Kivu, Congo (Wambeke, 1975).

${ }^{*} \mathrm{Al}$ was not measured in quantitative analysis because it was not detected in qualitative analysis.

${ }^{* *} \mathrm{H}_{2} \mathrm{O}$ was calculated by stoichiometry.

\section{DISCUSSION}

The general chemical formula of plumbogummite group minerals is $A B_{3}\left(X \mathrm{O}_{4}\right)_{2}\left(\mathrm{OH}, \mathrm{H}_{2} \mathrm{O}\right)_{6}$, where $A$ is a large cation site occupied by $\mathrm{Bi}$, REE, $\mathrm{Ca}, \mathrm{Sr}, \mathrm{Ba}$, and $\mathrm{Pb} ; B$ is an octahedral site occupied by $\mathrm{Al}, \mathrm{Fe}^{3+}$, and $\mathrm{V}^{3+} ; X$ is a tetrahedral site occupied by $\mathrm{P}$, minor $\mathrm{S}$ and As (Mills et al. 2010). Zairite $\left[\mathrm{BiFe}_{3}^{3+}\left(\mathrm{PO}_{4}\right)_{2}(\mathrm{OH})_{6}\right]$ and waylandite $\left[\mathrm{BiAl}_{3}\right.$ $\left.\left(\mathrm{PO}_{4}\right)_{2}(\mathrm{OH})_{6}\right]$ are plumbogummite group minerals including Bi and P. Zaïrite was originally described from Eta-Etu (Congo) reported by Wambeke (1975). Since then, a few locations had been reported in the world. Waylandite was first described by von Knorring and Mrose (1963), which was well reviewed by Clark et al. (1986) and Mills et al. (2010). The original zairite reported by Wambeke (1975) included $\mathrm{Al}$, replacing $22 \%$ of the $\mathrm{Fe}^{3+}$ site. On the other 
hand, zaïrite from Ishidera reported in this paper did not include any Al. This difference in chemical composition caused the difference in unit cell parameter, especially the $\boldsymbol{a}$-axis. The unit cell parameters of waylandite are $a=$ 6.9834(3) $\AA, c=16.175(1) \AA$ (Clark et al., 1986), which are smaller than those of zaïrite from Ishidera. Waylandite is composed of (001) sheets of corner-shared $\mathrm{AlO}_{6}$ octahedra and $\mathrm{PO}_{4}$ tetrahedra, stacked along the $c$-axis, with $\mathrm{Bi}$ atoms in icosahedral (12-fold coordinated) sites between the sheets (Mills et al., 2010). In the substitution of $\mathrm{Fe}^{3+}$ and Al, the octahedral frame work in the (001) sheet become larger with the increase in $\mathrm{Fe}^{3+}$, which had larger ionic radius than $\mathrm{Al}$, resulting as the elongation of the $\boldsymbol{a}$-axis. Same trend can been seen in unit cell parameters of plumbogummite $\left[\mathrm{PbAl}_{3}\left(\mathrm{PO}_{4}\right)\left(\mathrm{PO}_{3} \mathrm{OH}\right)(\mathrm{OH})_{6}\right]$ as $a=$ 7.017(1) $\AA$ and $c=16.75(1) \AA$ (Slansky, 1977); kintorenite $\left[\mathrm{PbFe}_{3}^{3+}\left(\mathrm{PO}_{4}\right)\left(\mathrm{PO}_{3} \mathrm{OH}\right)(\mathrm{OH})_{6}\right]$ as $a=7.2963(5) \AA$ and $c=$ 16.8491(5) $\AA$ (Grey et al., 2009), and the unit cell parameters ( $\boldsymbol{a}^{-}$and $\boldsymbol{c}$-axis length) of kintorenite are larger than those of plumbogummite. In the $\mathrm{Bi}$ site, because the ionic radius of $\mathrm{Bi}$ is similar to that of $\mathrm{Ca}$, the substitution of $\mathrm{Bi}$ and $\mathrm{Ca}$ did not cause much change of the unit cell parameters, as you can see from the unit cell parameters of crandallite $\left[\mathrm{CaAl}_{3}\left(\mathrm{PO}_{4}\right)\left(\mathrm{PO}_{3} \mathrm{OH}\right)(\mathrm{OH})_{6}\right]$ as $a=7.005(15) \AA$ and $c=16.192(32) \AA$ (Blount, 1974), which are very close to that of waylandite.

Plumbogummite group minerals take wide variation of chemical compositions accepting variable elements, which reflects the formation condition during hydrothermal alteration. In Ishidera area, florencite-(Ce) including REE also occurs as a plumbogummite group mineral similar to zaïrite and waylandite. Further study, including a reexamination of zaïrite from a type locality and a crystal structure analysis of zaïrite, is required to reveal their relationships and formation conditions.

\section{ACKNOWLEDGMENTS}

The authors would appreciate Dr. S. Uehara, Kyusyu University, for support to use of a microdiffractometer. We are grateful to two anonymous referees and associated editor, Dr. Takahiro Kuribayashi, for their constructive and critical reviews and editorial comments, respectively.

\section{SUPPLEMENTARY MATERIAL}

Color version of Figures 1 is available online from https://doi.org/10.2465/jmps.201130d.

\section{REFERENCE}

Blount, A.M. (1974) The crystal structure of crandallite. American Mineralogist, 59, 41-47.

Clark, A.M., Couper, A.G., Embrey, P.G. and Fejer, E.E. (1986) Waylandite: new data, from an occurrence in Cornwall, with a note on 'agnesite'. Mineralogical Magazine, 50, 731-733.

Grey, I.E., Mumme, W.G., Mills, S.J., Birch, W.D. and Willson, N.C. (2009) The crystal chemical role of $\mathrm{Zn}$ in alunite-type minerals: Structure refinements for kintoreite and zincian kintoreite. American Mineralogist, 94, 676-683.

Mills, S.J., Kampf, A.R., Raudsepp, M. and Birch, W.D. (2010) The crystal structure of waylandite from Wheal Remfry, Cornwall, United Kingdom. Mineralogy and Petrology, 100, 249253.

Ozaki, M., Sangawa, A., Miyazaki, K., Nishioka, Y., et al. (2000) Geology of the Nara district. With geological sheet map at 1:50000. pp. 162, Geological Survey of Japan (in Japanese with English abstract).

Shimobayashi, N., Ohnishi, M. and Tsuruta, K. (2012) Secondary tungsten minerals in quartz veins in the Ishidera area, Wazuka, Kyoto Prefecture, Japan: anthoinite, mpororoite, and Fe-free hydrokenoelsmoreite. Journal of Mineralogical and Petrological Sciences, 107, 33-38.

Shirose, Y., Enju, S., Tsuruta, K. and Shimobayashi, N. (2018) Bismuth minerals from Ishidera, Wazuka, Kyoto Prefecture, Japan. The Abstracts with Programs 2018 Annual Meeting of Japan Association of Mineralogical Sciences, R1-P14, https:// www.jstage.jst.go.jp/article/jakoka/2018/0/2018_49/_article/ -char/en (in Japanese with English abstract)

Slansky, E. (1977) Plumbogummite from Ivanhoe mine, Northern Territory, Australia. Neues Jahrbuch für Mineralogie, Monatshefte, 45-53.

Takeuchi, K. and Wang, G.F. (1999) The low-grade Ryoke metamorphic rocks in the Wazuka district, Kyoto Prefecture, Japan. Bulletin of the Geological Survey of Japan, 50, 8, 527534 (in Japanese with English abstract).

Tsuruta, K., Ohnishi, M. and Ohnishi, A. (2008) Phosphate, tungstate and beryllium minerals from the Ishidera district, Wazuka, Kyoto Prefecture, Japan. CHIGAKUKENKYU, 57, 67-73 (in Japanese).

von Knorring, O. and Mrose, M.E. (1963) New mineral data. American Mineralogist, 48, 216.

Wambeke, L.V. (1975) La zaïrite, un nouveau minéral appartenant à la série de la Crandallite. Bulletin de la Société française de Minéralogie et de Cristallographie, 98, 351-353 (in French with English abstract).

Wang, G.F., Banno, S. and Takeuchi, K. (1986) Reactions to define the biotite isograd in the Ryoke metamorphic belt, Kii Peninsula, Japan. Contributions to Mineralogy and Petrology, 93, 9-17.

Manuscript received November 30, 2020

Manuscript accepted March 10, 2021

Published online April 27, 2021

Manuscript handled by Takahiro Kuribayashi 